\title{
Subcellular Localization of Activated AKT in Estrogen Receptor- and Progesterone Receptor-Expressing Breast Cancers
}

\section{Potential Clinical Implications}

\author{
Sunil Badve, ${ }^{*}$ Nikail R. Collins, ${ }^{\dagger}$ \\ Poornima Bhat-Nakshatri, ${ }^{\dagger}$ Dmitry Turbin, ${ }^{\ddagger}$ \\ Samuel Leung, ${ }^{\ddagger}$ Mangesh Thorat, ${ }^{*}$ \\ Sandra E. Dunn, ${ }^{\S}$ Tim R. Geistlinger, " \\ Jason S. Carroll," Myles Brown, "Shikha Bose," \\ Michael A. Teitell, ${ }^{* \star}$ and Harikrishna Nakshatri ${ }^{\dagger, t+\ddagger \ddagger}$ \\ From the Departments of Pathology and Internal Medicine,* \\ Surgery, ${ }^{\dagger}$ Biochemistry and Molecular Biology, ${ }^{\dagger+}$ and the Walther \\ Oncology Center, ${ }^{\neq}$Indiana University School of Medicine, \\ Indianapolis, Indiana; the Genetic Pathology Evaluation Centre, \\ Vancouver Hospital and Health Sciences Center, Vancouver, \\ British Columbia, Canada; the Child and Family Research \\ Institute,, University of British Columbia, Vancouver, British \\ Columbia, Canada; the Division of Molecular and Cellular \\ Oncology, Dana-Farber Cancer Institute and Department of \\ Medicine, "Brigham and Women's Hospital and Harvard \\ Medical School, Boston, Massachusetts; the Department of \\ Pathology," Cedars Sinai Medical Center, Los Angeles, California; \\ and the Department of Pathology and Broad Stem Cell Research \\ Center,** UCLA School of Medicine, Los Angeles, California
}

Activated v-AKT murine thymoma viral oncogene homolog 1 (AKT)/protein kinase B (PKB) kinase (pAKT) is localized to the plasma membrane, cytoplasm, and/or nucleus in $50 \%$ of cancers. The clinical importance of pAKT localization and the mechanism(s) controlling this compartmentalization are unknown. In this study, we examined nuclear and cytoplasmic phospho-AKT (pAKT) expression by immunohistochemistry in a breast cancer tissue microarray ( $n=$ 377) with $\approx 15$ years follow-up and integrated these data with the expression of estrogen receptor (ER) $\alpha$, progesterone receptor (PR), and FOXA1. Nuclear localization of pAKT (nuclear-pAKT) was associated with long-term survival $(P=0.004)$. Within the $E R \alpha+$ / PR+ subgroup, patients with nuclear-pAKT positivity had better survival than nuclear-pAKT-negative pa- tients $(P \leq 0.05)$. The association of nuclear-pAKT with the $E R \alpha+/ P R+$ subgroup was validated in an independent cohort $(n=145)$. TCL1 family proteins regulate nuclear transport and/or activation of AKT. TCL1B is overexpressed in ER $\alpha$-positive compared with $\mathrm{ER} \alpha$-negative breast cancers and in lung metastasis-free breast cancers. Therefore, we examined the possible control of TCL1 family member(s) expression by the estrogen:ER $\alpha$ pathway. Estradiol increased TCL1B expression and increased nuclear-pAKT levels in breast cancer cells; short- interfering RNA against TCL1B reduced nuclear-pAKT. Overexpression of nuclear-targeted AKT1 in MCF-7 cells increased cell proliferation without compromising sensitivity to the anti-estrogen, tamoxifen. These results suggest that subcellular localization of activated AKT plays a significant role in determining its function in breast cancer, which in part is dependent on TCL1B expression. (Am J Pathol 2010, 176:2139-2149; DOI: 10.2353/ajpath.2010.090477)

The serine/threonine kinase AKT is a multifunctional kinase that is activated in response to a variety of extracellular signals. ${ }^{1-3}$ Inactive AKT from the cytosol is recruited to the plasma membrane in the presence of phosphoinositide triphosphate, where it is activated by phosphorylation of residues T308 by phosphoinositide-

Supported by grants from the National Institutes of Health to M.A.T. (CA90571, CA107300) and H.N. (CA89153). M.T. is a Leukemia and Lymphoma Society Scholar. H.N. is Marian J. Morrison Professor of Breast Cancer Research

Accepted for publication January 21, 2010

Supplemental material for this article can be found on http://ajp. amjpathol.org

Address reprint requests to Harikrishna Nakshatri, Ph.D., Indiana University School of Medicine, 1044 West Walnut St, R4-202, Indianapolis, IN 46202; or Sunil Badve, M.D., FRCPath, Clarian Pathology Laboratory, 350 West 11th St., Suite 4050, Indianapolis, IN 46202. E-mail: hnakshat@ iupui.edu or sbadve@iupui.edu. 
dependent kinase 1 (PDK1) and S473 by mTOR/rictor or unidentified kinase(s). ${ }^{1,2,4}$ Activated AKT, as measured mostly by antibodies that recognize phosphorylated AKT at S473 (pAKT), can be found at the plasma membrane, in the cytoplasm, and in the nucleus. ${ }^{1}$

Activation of $A K T$, either due to a point mutation or point mutations in the upstream $\mathrm{Pl} 3$ kinase, or loss of the upstream tumor suppressor PTEN, or growth factor overexpression, is observed in $\approx 50 \%$ of all cancers. ${ }^{2,5-7}$ The carcinogenic action of AKT, until recently, was believed to arise exclusively from the cytoplasm, possibly through regulation of cell size, energy metabolism, and translational control. ${ }^{1,8}$ However, recent studies have identified a pool of activated AKT within the nucleus (nuclearpAKT), where it can block apoptosis. ${ }^{1,9}$ Indeed, studies in cardiomyocytes have revealed gender-specific differences in the subcellular localization of pAKT. ${ }^{10}$ Elevated nuclear-pAKT found in cardiomyocytes of premenopausal women, as compared with men or postmenopausal women, is thought to be cardioprotective. ${ }^{11,12}$ These studies strongly suggest distinct biological actions for cytoplasmic and nuclear-pAKT, which may be controlled by sex hormones. Thus, AKT activity and/or localization may be different in estrogen receptor-positive (ER $\alpha$-positive) and $E R \alpha$ negative breast cancers.

ER $\alpha$-positive breast cancers are further subclassified into luminal type $A$ and luminal type $B .{ }^{13}$ Luminal type $A$ breast cancers are associated with elevated expression of transcription factors progesterone receptor (PR), FOXA1, and GATA-3. ${ }^{13-15}$ ER $\alpha$, FOXA1, and GATA-3 form a transcription factor network that determines hormonal response and hence anti-estrogen sensitivity of luminal type A breast cancers. ${ }^{16}$ In contrast, luminal type $B$ breast cancers are associated with increased expression of proliferation-associated genes including Ki-67. ${ }^{17}$ These cancers can be either ER $\alpha$-positive or PR-positive and include a small subfraction of ER $\alpha$-positive breast cancers that overexpress HER2. The status of activated AKT and its subcellular distribution in both types of $E R \alpha-$ positive luminal breast cancers are unknown.

To determine subcellular distribution status of activated $\mathrm{AKT}$ and its relationship to $\mathrm{ER} \alpha$ status, we investigated the distribution pattern of pAKT in a tissue microarray (TMA) comprising samples from 377 patients with $\approx 15$ years of clinical follow-up, and also an independent analysis of a second TMA, comprising 118 invasive breast carcinomas. We report preferential nuclear localization of pAKT in ER $\alpha$-positive breast cancers and the luminal $A$ subtype. Furthermore, we show that a TCL1B-dependent estrogen:ER $\alpha$-regulated signaling pathway partly controls the activation of nuclear AKT.

\section{Materials and Methods}

\section{Patient Information and Tissue Microarray}

Patient information, tumor pathology, and the expression of a number of biomarkers in a tissue microarray (GPECTMA) comprising 438 patient samples have been reported previously. ${ }^{18}$ The histological distribution included infiltrating ductal carcinoma $(n=379)$, infiltrating lobular carcinoma $(n=41)$, and special types $(n=8)$. Because of the loss of cores during the staining process with one or more stains, the final analysis included data from 377 patients. Median age and median survival years were 61.48 and 11.93, respectively. The second TMA (Cedars Sinai-UCLA Medical Center) with 145 cases of invasive carcinoma that was used for validation of results has also been described previously. ${ }^{19,20}$ This study was performed under human institutional review board approval with strict adherence to all established guidelines.

\section{Immunohistochemistry}

Immunohistochemistry for pAKT (S473), ER $\alpha$, PR, FOXA1, and GATA-3 has been described previously. ${ }^{18}$ Samples that did not stain were classified as negative (score 0), whereas those showing the highest intensity staining received a score of 3 . Samples showing weak intensity staining received a score of 1 , whereas those showing moderate staining were scored as 2. Samples were stratified based on the nuclear versus cytoplasmic localization of PAKT. Two pathologists scored the staining intensities and nuclear versus cytoplasmic staining pattern of PAKT.

\section{Statistical Analysis of Clinical Data}

Unsupervised hierarchical clustering involving four variables, ER $\alpha$, PR, FOXA1, and PAKT, was performed using Genesis 1.6.0 $\beta 1$ software. ${ }^{21}$ Clustering was based on all 438 patients. One of the groups consisted of cases with missing data for $\mathrm{ER} \alpha, \mathrm{PR}, \mathrm{FOXA1}$, and PAKT (including those with missing cores). This group was not further analyzed. The Kaplan-Meier method was used for survival analysis, and hazard ratios were calculated using a log-rank test. A $P$ value of less than 0.05 was considered as significant. All survival and correlation analyses were performed using SPSS 16.0 (SPSS Inc, Chicago, IL).

\section{Antibodies}

ER $\alpha$ antibodies used for chromatin immunoprecipitation (ChIP) were: ab 10 (Neomarker, Fremont, CA) and ER $\alpha$ sc-543 (Santa Cruz Biotechnologies, Santa Cruz, CA). poly(ADP-ribose) polymerase (PARP) (Santa Cruz Biotechnologies, Santa Cruz, CA) and $\alpha$-Tubulin (Sigma, St. Louis, MO) were used to ensure separation of nuclear and cytoplasmic proteins. Antibodies against AKT, pAKT, and a Hemagglutinin (HA)-tag were purchased from Cell Signaling Technologies (Danvers, MA). TCL1B antibody was purchased from Santa Cruz Biotechnologies.

\section{Plasmid Constructs, Retroviral Transfection, and Cell Proliferation Assays}

HA-tagged wild-type AKT1, AKT1 with a T308D/S473D mutation (HA-AKT-CA), and a $\triangle$ NES- mutant (L277A/ L280A/L282A) in pcDNA3 vector have been described. ${ }^{22}$ Wild-type AKT1, mutant AKT1, and TCL1B expressing 
retroviruses were constructed using the bicistronic expression vector pcQXIN, packaged, and used for MCF-7 and/or T47-D cell infections. ${ }^{23}$ Infected cells were selected using G418 (600 mg/ml), and polyclonal cultures were analyzed. Cell proliferation was measured by BrdUELISA assay (EMD Biosciences, La Jolla, CA). All studies were done with cells maintained in phenol red-free charcoal dextran-treated fetal calf serum (CCS-5\%)-containing media for at least four days before initiating experiments. Most of the cell fractionation studies were done with cells that were additionally maintained overnight in media with $1 \%$ CCS. Cells in studies involving siRNA transfections were transfected in regular media and changed to the phenol red-free 5\% CCS media 24-hours after transfection to avoid transfection-associated toxicity.

\section{ChIP Assays}

ChIP coupled microarray assays were performed as described previously. ${ }^{24}$

\section{RNA, Northern Analysis, and Reverse Transcription or Real-Time Polymerase Chain Reaction (RT-PCR)}

RNA was prepared using Qiagen RNAeasy kits (Valencia, CA) and subjected to Northern blotting or RT-PCR as described previously. ${ }^{23,25}$ TCL1B primers used for RTPCR were: 5'-CAGCAGATATGAACCCAGCA-3' (forward primer) and 5'-TCTTTCCTCTCCGGCTGATA-3' (reverse primer).

Real-time PCR (Q-PCR) primers were: 5'-TTGGCCCGAAATAGATCCAGTGCT-3' (forward primer) and 5'ATAAGCAGAAGCACAGGCCAAACC-3' (reverse primer). Real-time PCR was done using Syber Green (Applied Biosciences, Foster City, CA).

\section{siRNA Transfections and Western Blotting}

siRNA against TCL1B (on-TARGETplus Duplex J-01989205-0005) and the luciferase control were purchased from Dharmacon (Lafayette, CA) and transfected into MCF-7 or T47-D cells using the nucleofector reagent (Amaxa, Gaithersburg, MD). Cells were harvested four or six days after transfection, and nuclear and cytoplasmic extracts were prepared as described previously and probed with the indicated antibodies. ${ }^{26}$ Densitometric scanning was performed to determine the intensity of signals in each lane. Statistical analysis of Western blot data $(n \geq 3)$ was performed using GraphPad software (GraphPad Software, Inc., San Diego, CA).

\section{Results}

\section{Preferential Nuclear Accumulation of PAKT in ER $\alpha$-Positive Breast Cancers}

Breast cancer tissue microarrays were stained for PAKT (S473) and scored based on intensity and localization.

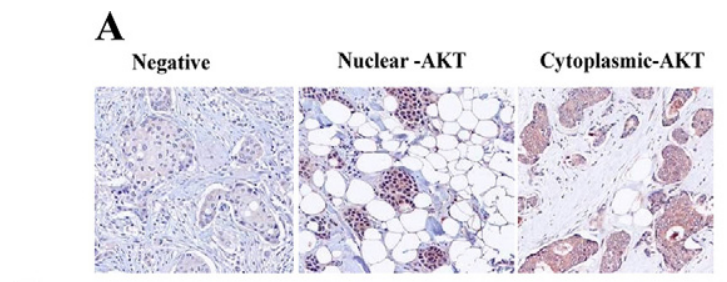

B

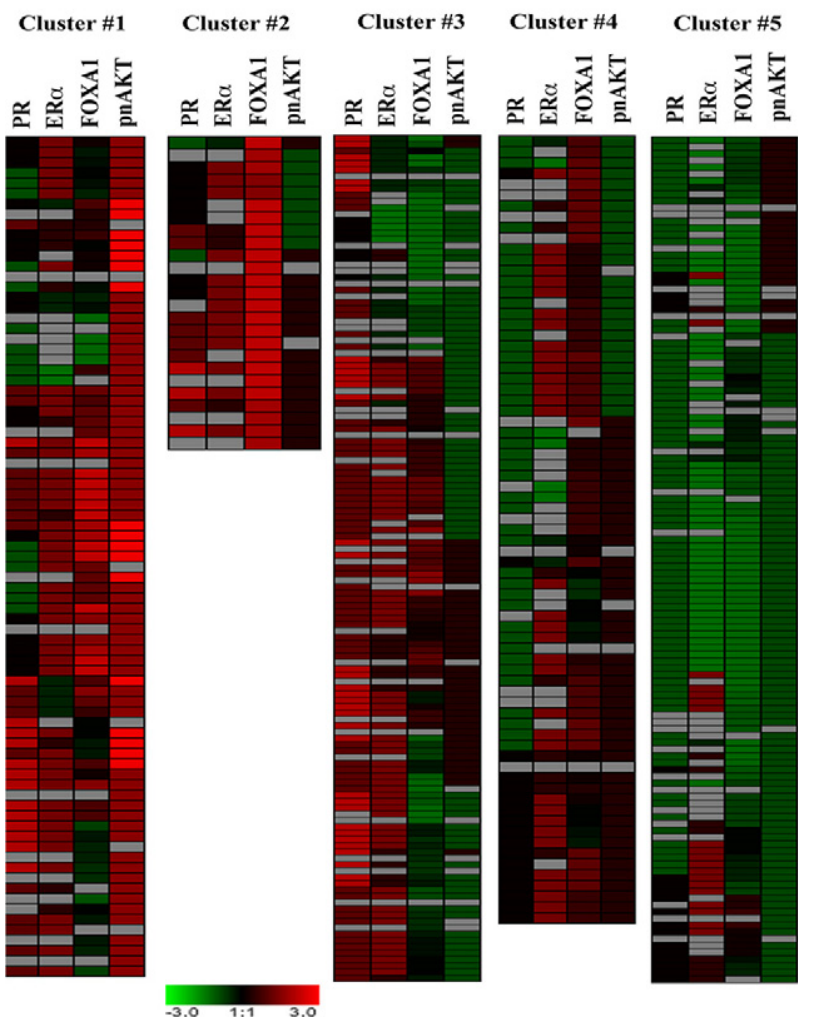

Figure 1. A: Representative pAKT (S473) staining pattern in primary breast cancer. Tumors with no pAKT staining, nuclear, and cytoplasmic staining are shown. B: Heatmap showing subclassification of patients based on ER $\alpha, P R$, FOXA1, and activated nuclear AKT expression patterns.

Four distinct patterns of pAKT expression were observed in breast cancer samples: no pAKT, exclusively nuclear (nuclear-pAKT, 62 tumors), exclusively cytoplasmic (cytoplasmic-pAKT, 293 tumors), and distributed both in the nucleus and cytoplasm pAKT ( $n=15$; Figure 1A).

We examined the relationship between the subcellular distribution of pAKT and intrinsic subtypes (ie, luminal subtypes $A$ and $B, H E R 2+/ E R \alpha-$, basal-like, and normallike). ${ }^{13,27}$ Although both the luminal subtypes are $E R \alpha-$ positive, subtype $A$ expresses higher levels of $\mathrm{ER} \alpha$ and FOXA1 (a cofactor for $\mathrm{ER} \alpha$ ) and has better prognosis than subtype B. ${ }^{13,15,28}$ Tumors with nuclear-pAKT were predominantly of luminal type A subtype as well as positive for $\mathrm{ER} \alpha$, FOXA1, and GATA-3 (which was previously linked to ER $\alpha$ and FOXA1 positivity ${ }^{13}$; Table 1). In contrast, cytoplasmic-pAKT correlated with HER2-positivity.

To further explore the relationship between $\mathrm{ER} \alpha$ and nuclear-pAKT, we evaluated the PAKT distribution pattern in an independent set of patients. ${ }^{20}$ A TMA of 118 samples from Cedars Sinai-UCLA Medical Center was scored for nuclear-pAKT; 47 cases showed nuclear- 
Table 1. Correlation Analysis of Phospho-AKT (Nuclear or Cytoplasmic) with Other Markers

\begin{tabular}{lrll}
\hline \multicolumn{1}{c}{ Variables } & $\begin{array}{c}\text { Correlation } \\
\text { coefficient }\end{array}$ & $\begin{array}{c}P \text { value } \\
(2 \text {-tailed) }\end{array}$ & $\begin{array}{c}\text { Number of } \\
\text { patients }\end{array}$ \\
\hline Nuclear phospho-AKT & & & \\
FOXA1 & 0.253 & 0.000001 & 377 \\
ER $\alpha$ & 0.254 & 0.0000007 & 302 \\
GATA-3 & 0.262 & 0.000001 & 357 \\
Luminal subtype A & 0.146 & 0.009 & 321 \\
Luminal subtype B & 0.007 & 0.895 & 321 \\
HER2 & -0.058 & 0.285 & 322 \\
Cytoplasmic & & & \\
$\quad$ phospho-AKT & & & \\
FOXA1 & 0.177 & 0.001 & 364 \\
Luminal subtype A & 0.095 & 0.91 & 315 \\
Luminal subtype B & 0.044 & 0.435 & 315 \\
ER $\alpha$ & 0.107 & 0.170 & 309 \\
HER2 & 0.139 & 0.012 & 344 \\
\hline
\end{tabular}

Luminal type $\mathrm{A}$ is defined as ER $\alpha+$ and/or PR+, HER2-, whereas luminal type B represents tumors that are $\mathrm{ER} \alpha+$ and/or $\mathrm{PR}+$, HER $2+{ }^{31}$

pAKT expression. Within this TMA, nuclear-pAKT also correlated with ER $\alpha+/ \mathrm{PR}+$ and $\mathrm{ER} \alpha+/ \mathrm{FOXA} 1+$, and luminal A phenotype and negatively with HER2 (Table 2). Thus, nuclear-pAKT expression is associated with luminal type A breast cancers as defined by $\mathrm{ER} \alpha+$ and/or $\mathrm{PR}+$ phenotype.

\section{Nuclear-pAKT Expression in ER $\alpha$-Positive Breast Cancer Is Associated with Better Survival}

The presence of PAKT is usually considered a poor prognostic indicator, irrespective of cancer type. ${ }^{1,29}$ However, none of these prior studies, with the exception of one prostate cancer study, evaluated prognostic significance of differential subcellular PAKT expression. ${ }^{30}$ We used $\mathrm{ER} \alpha, \mathrm{FOXA1}, \mathrm{PR}$, and nuclear-pAKT expression patterns to classify patients into subgroups that were correlated with patient survival. Because of the larger sample size and availability of $\approx 15$-year follow-up data, only the GPEC-TMA was used for survival analysis. Combining two datasets was not feasible as these two datasets originated from different institutions and contained follow-up data for different durations. Unsupervised hierarchical clustering identified five subgroups: (1) $\mathrm{ER} \alpha+$ / PR+/FOXA1+/nuclear-pAKT+; (2) ER $\alpha+/ P R+/ F O X A 1+/$

Table 2. Nuclear Phospho-AKT Analysis in Second TMA

\begin{tabular}{lrcc}
\hline \multicolumn{1}{c}{ Variable } & $\mathrm{n}$ & $\begin{array}{c}\text { Correlation } \\
\text { coefficient }\end{array}$ & $\begin{array}{c}P \text { value } \\
\text { (2-tailed) }\end{array}$ \\
\hline ER $\alpha+/$ PR+ & 104 & 0.204 & 0.024 \\
ER $\alpha+/ F O X A 1+$ & 85 & 0.228 & 0.022 \\
Luminal subtype A & 89 & 0.257 & 0.015 \\
Luminal subtype $B^{*}$ & 89 & -0.058 & 0.592 \\
HER2 & 89 & -0.223 & 0.036 \\
\hline
\end{tabular}

Correlation of n-pAKT expression with ER $\alpha+/ P R+$ status, ER $\alpha+/$ FOXA1+ status, HER2 and luminal breast cancer subtypes was performed in a second TMA composed of 145 breast cancer samples.

*Luminal type $\mathrm{A}$ is defined as ER $\alpha+$ and/or PR+, HER2-, whereas luminal B subtype represents tumors that are $\mathrm{ER} \alpha+$ and/or $\mathrm{PR}+$, HER $2+.{ }^{31}$
nuclear-pAKT-; (3) $\quad \mathrm{ER} \alpha+/ \mathrm{PR}+/ \mathrm{FOXA} 1 \pm($ low $) /$ nuclearpAKT-; (4) ER $\alpha+/$ PR-/FOXA1+/nuclear-pAKT-; and (5) ER $\alpha$-/ PR-/FOXA1-/ nuclear-pAKT- (Figure 1B). Survival curves of each subgroup are shown in Figure 2A. Statistical comparison among various subgroups along with $95 \%$ bootstrap confidence interval of mean biomarker scores for each cluster is shown in supplemental Table S1 and S2 (at http://ajp.amjpathol.org). As expected, the ER $\alpha$-negative subgroup showed the worst survival rate.

We performed survival analysis of ER $\alpha+/ F O X A 1+$ patients (luminal type A subtype ${ }^{31}$ ) based on nuclear-pAKT expression. The presence of nuclear-pAKT in this patient subgroup ( $n=176$ ) was associated with better survival, emphasizing the importance of evaluating PAKT levels based on subcellular distribution patterns in clinical settings $(P=0.037$, Figure $2 \mathrm{~B})$. Similar results were observed when $E R \alpha+/ P R+$ patients were subgrouped based on nuclear-pAKT expression (Figure 2C, $P=$ 0.05). We also performed survival analysis of patients based on the nuclear-pAKT alone. Patients with no nuclear-pAKT displayed worse survival than patients with moderate and strong $(2+$ and $3+)$ levels of nuclear-pAKT $(P=0.004$, Figure 2D). Thus, a clear association of nuclear-pAKT expression with better survival was observed in all of the above analyses performed with this dataset.

When patients in luminal type A cluster were analyzed separately (ER $\alpha+$ or PR+ and HER2-negative ${ }^{31}$ ), nuclearpAKT + patients showed a trend toward better survival, although difference in survival did not reach statistical significance $(P=0.111$, univariate log-rank test, no staining versus $2+/ 3+$ pAKT staining, Figure $3 A$ ). In multivariate Cox regression model involving nuclear-pAKT, age, grade, nodal status, and tumor size among luminal $A$ patients revealed grade $(P=0.019)$, nodal status $(P=$ $0.002)$, and tumor size $(P=0.009)$ as independent predictors of survival. Age and nuclear pAKT $(P=0.172)$ did not reach statistical significance in this model.

Clustering analysis of $\mathrm{ER} \alpha, \mathrm{PR}, \mathrm{FOXA} 1$, and cytoplasmic-pAKT identified four clusters (see supplemental Table S3 at $h$ ttp://ajp.amjpathol.org); one of these clusters had to be excluded from interpretation because it was formed from cases with missing data for most of these markers. There was no difference in survival rates in the remaining three clusters indicating that cytoplasmicPAKT had no prognostic value (Figure 3B; see Table S1 at $h$ ttp://ajp.amipathol.org for $P$ values). Results of this cluster analysis are consistent with previous univariate analysis from this TMA, showing the lack of correlation between cytoplasmic pAKT and patient survival. ${ }^{18}$ Note that tumors with cytoplasmic-pAKT are also positive for FOXA1, which is a good prognostic marker of ER $\alpha$-positive breast cancer. ${ }^{15}$ Patients in cluster \#4 of the cytoplasmic-pAKT group are similar to patients in cluster \#1 of the nuclear-pAKT group with respect to intensity of $\mathrm{ER} \alpha, \mathrm{PR}$, and FOXA1 staining. Their survival rate, however, was worse than patients with nuclear-pAKT $(72 \%$ versus $83 \%$ survival, $P=0.048$ ), which suggests that patients with tumors positive for nuclear-pAKT have better prognosis than those positive for cytoplasmic-pAKT. 
$\mathbf{A}$

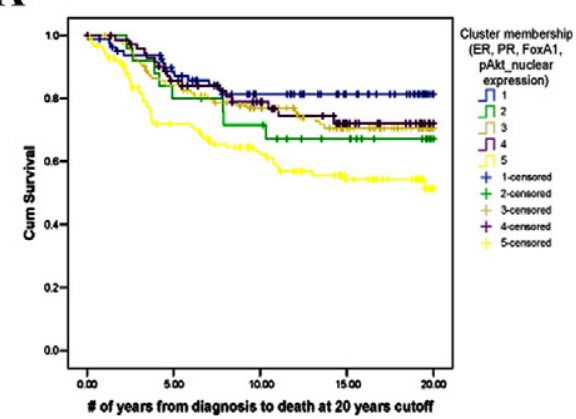

C

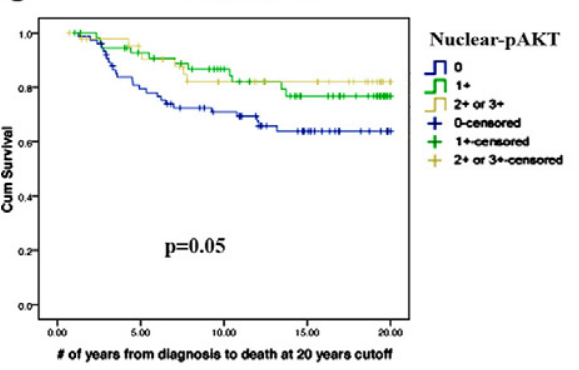

B

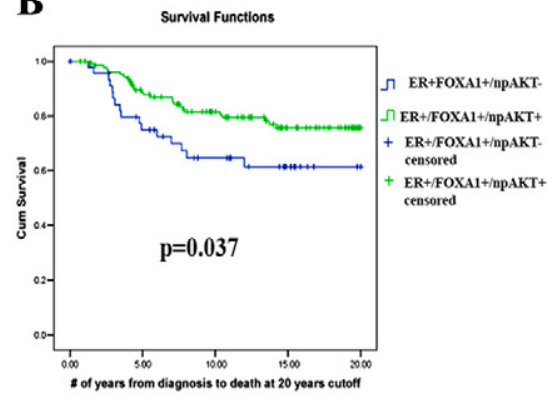

D

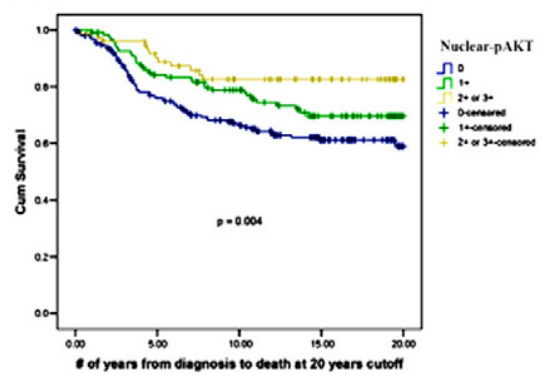

Figure 2. A: Kaplan-Meier survival plot demonstrating overall survival among patients subgrouped based on four variables: ER $\alpha$, PR, FOXA1, and nuclear pAKT. Unsupervised hierarchical clustering was used to subgroup patients. Cluster \#1, ER $\alpha+$ $\mathrm{PR}+/$ FOXA1+/nuclear-pAKT+; cluster \#2, ER $\alpha+$ / PR+/FOXA1+/nuclear-pAKT-; cluster \#3, $\mathrm{ER} \alpha+/ \mathrm{PR}+/$ FOXA1 \pm /nuclear-pAKT-; cluster \#4, $\mathrm{ER} \alpha+/ \mathrm{PR}-/$ FOXA1+/nuclear-pAKT-; cluster \#5, ER $\alpha$-/PR-/FOXA1-/nuclear-pAKT-. B: Kaplan-Meier survival plot demonstrating overall survival among ER $\alpha+$ /FOXA1+ patients with or without nuclear-pAKT. C: Kaplan-Meier survival plot demonstrating overall survival among $\mathrm{ER} \alpha+/ \mathrm{PR}+$ patients with or without nuclearpAKT. $P=0.05$, nuclear-pAKT + versus nuclearpAKT- groups. D: Kaplan-Meier survival plot demonstrating overall survival of patients with or without nuclear-pAKT.

\section{TCL1B Is an Estradiol (E2)-Inducible Gene that Partly Controls Activation of Nuclear-AKT}

Our results suggested a direct involvement of ER $\alpha$-regulated signaling pathways in the nuclear translocation of
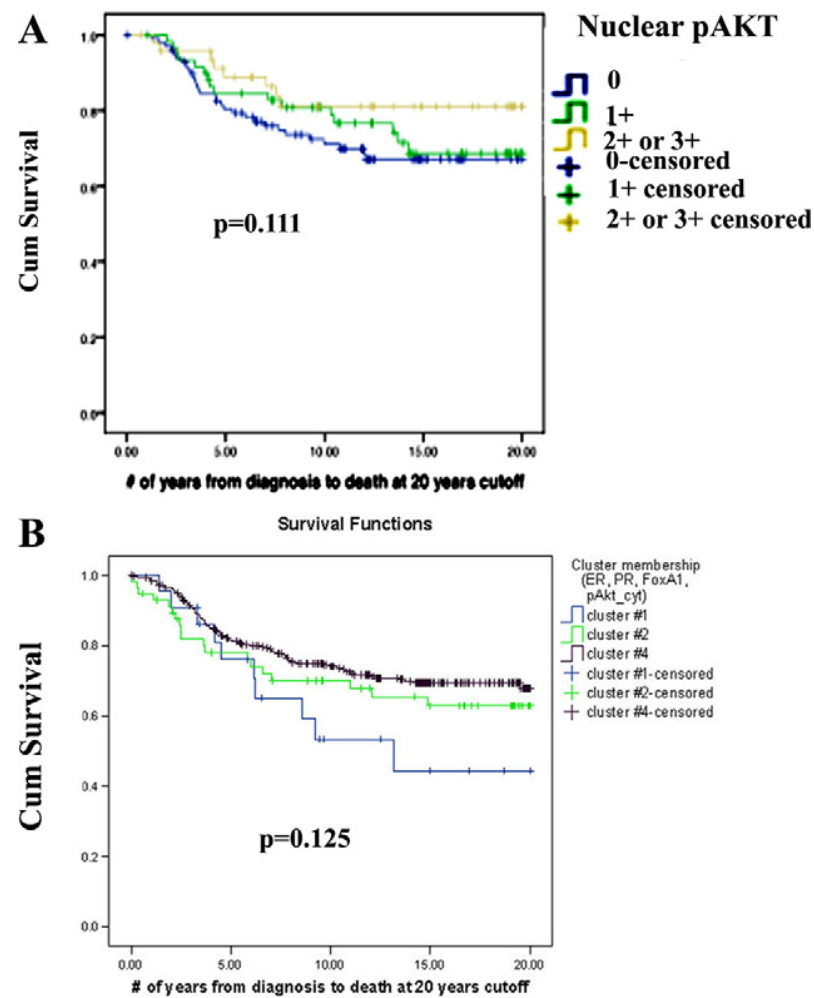

Figure 3. A: Kaplan-Meier survival plot demonstrating overall survival among luminal type A patients with or without nuclear-pAKT. B: Kaplan-Meier survival plot demonstrating overall survival among patients subgrouped based on four variables: ER $\alpha, \mathrm{PR}, \mathrm{FOXA1}$, and cytoplasmic-pAKT. Cluster $\# 1, \mathrm{ER} \alpha+/ \mathrm{PR}+/$ FOXA1-/cytoplasmic-pAKT-; cluster $\# 2$, ER $\alpha$-/PR-/FOXA1-/cytoplasmicpAKT+; cluster \#4, ER $\alpha+/$ PR+/FOXA1+/cytoplasmic-pAKT+.
PAKT or activation of nuclear AKT. Loss of PML expression and elevated zyxin expression are linked to the presence of nuclear-pAKT in prostate cancer cells. ${ }^{32,33}$ However, these are less likely candidates for E2-regulated activation of nuclear AKT because PML is an E2inducible gene, whereas zyxin is not a target of E2 (data not shown $\left.{ }^{23}\right)$.

TCL1 family oncogenes, which include TCL1A, TCL1B, and MTCP1, function as co-activators for PAKT and enhance AKT nuclear translocation and/or activation. ${ }^{34-36}$ To test E2 regulation of the TCL1 family oncogenes expression, we sought to identify AKT-induced changes in $\mathrm{ER} \alpha$ binding patterns within the genome using ChIPcoupled microarray (ChIP-chip). ${ }^{23}$ An ER $\alpha$ binding site at the $3^{\prime}$ end of TCL1B gene but not other TCL1 family genes was detected in MCF-7 cells overexpressing constitutively active AKT (Figure 4A). This region of TCL1B gene contains the sequence GGTCAgggTGACC, which is a perfect palindromic estrogen response element, and multimerized forms of these elements show E2-dependent activity in transient transfection assays. ${ }^{37}$ We confirmed E2-inducible expression of TCL1B in ER $\alpha$-positive MCF-7 and T47-D breast cancer cells by RT-PCR (Figure $4 \mathrm{~B}$, left panel) and Q-PCR (Figure 4B, right panel). Unfortunately, endogenous TCL1B protein could not be measured because available antibodies recognized only overexpressed proteins (see below) or recombinant proteins.

T47-D cells contained 4.8-fold higher basal levels of TCL1B than MCF-7 cells (Figure 5A, left and central panels). Accordingly, basal nuclear-pAKT level was higher in T47D cells than in MCF-7 cells (Figure 5A, right panel). E2 treatment of T47-D cells caused a further increase in nuclear-pAKT levels (Figure 5B). These results suggest that nuclear AKT is activated in these cells, and E2 further increases nuclear-pAKT levels. E2 simi- 
A
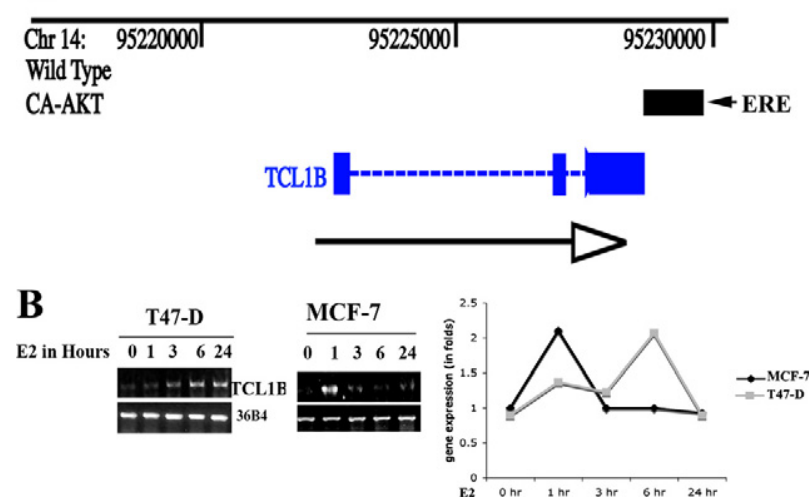

Figure 4. E2 regulates TCL1B expression and nuclear-pAKT levels. A: ER $\alpha$-binding site near TCL1B gene. Position of the TCL1B gene on chromosome 14 (Chr14) is shown along with an ER $\alpha$ binding site detected in E2 treated (one hour, $10^{-8} \mathrm{~mol} / \mathrm{L}$ ) MCF-7 cells overexpressing constitutively active AKT (black bar). Black arrow indicates direction of the gene. TCL1B structure with three exons (blue bars) is also displayed. B: E2-inducible expression of TCL1B in MCF-7 and T47-D cells measured by RT-PCR (left) or Q-PCR (right) is shown. The PCR product was sequenced to confirm that the amplified product corresponds to TCL1B.

larly increased nuclear-pAKT levels in MCF-7 cells, which ranged from 1.3 to 4 -fold between experiments (Figure $5 \mathrm{C}$, see below).

\section{The Effects of TCL1B Manipulation on Nuclear-pAKT and Cell Proliferation}

To directly determine the role of TCL1B in activation of AKT, we reduced the levels of TCL1B using siRNA against TCL1B in T47-D cells. siRNA reduced TCL1B transcript levels by $\approx 35 \%$ (Figure $6 \mathrm{~A}$, left and central panel). We also determined the effect of siRNA on TCL1B protein levels using T47D cells overexpressing TCL1B to
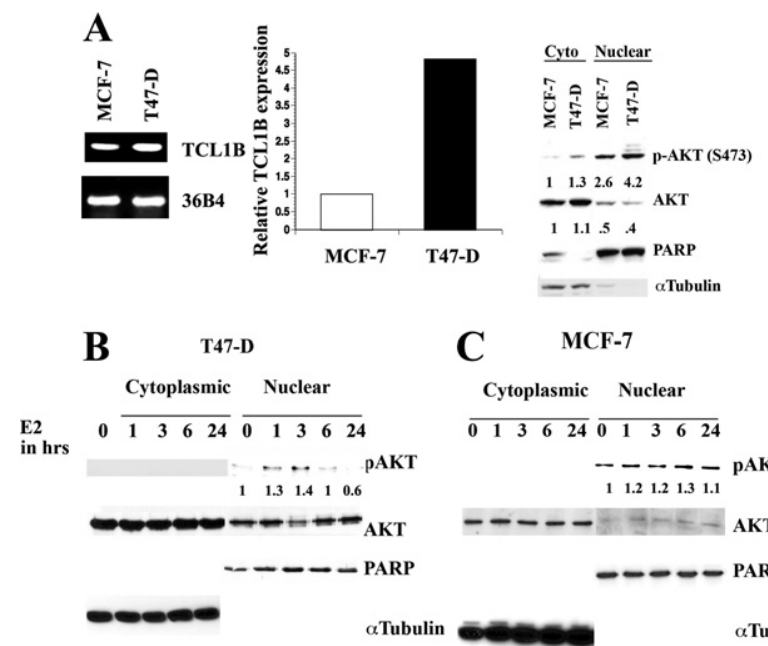

$$
\text { C MCF-7 }
$$
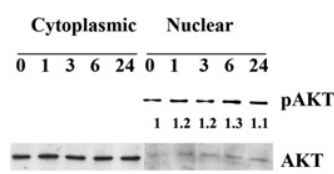

- - - PARP

$\alpha$ Tubulin

Figure 5. The effects of E2 on nuclear-pAKT in MCF-7 and T47-D cells. A: T47-D expresses higher levels of TCL1B than MCF-7 cells. Semiquantitative RT-PCR (left) or qRT-PCR (middle) was used to measure TCL1B levels. Basal cytoplasmic and nuclear-pAKT levels in MCF-7 and T47-D cells are shown in the right panel. The blot was reprobed with PARP and $\alpha$-Tubulin antibodies to ensure purity of nuclear and cytoplasmic extracts. The nuclear-pAKT levels were normalized to PARP levels. B and C: E2 increases nuclear-pAKT in T47-D and MCF-7 cells.
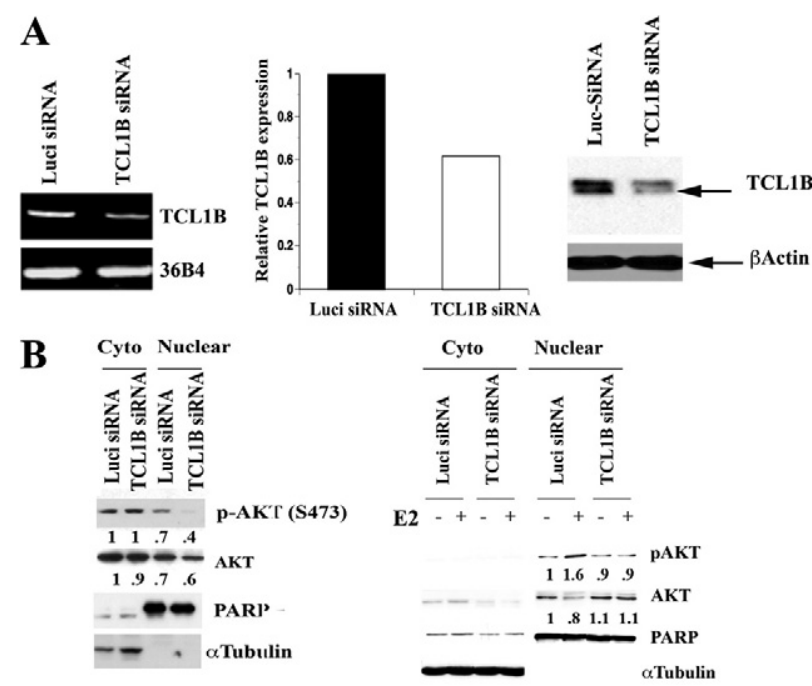

C

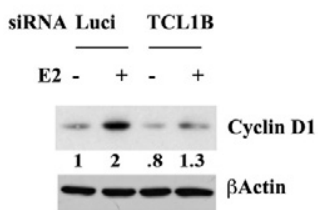

Figure 6. TCL1B controls basal and E2-induced activation of nuclear AKT. A: TCL1B specific siRNA reduces TCL1B transcript levels in T47-D cells. Data from both RT-PCR and qRT-PCR from two independent experiments are shown (left and middle). The effect of TCL1B siRNA on TCL1B protein was confirmed using TCL1B overexpressing T47D cells (right). B: siRNA against TCL1B reduces basal and E2-induced nuclear-pAKT in T47-D cells. Cells were transfected with siRNA targeting either TCL1B or luciferase (Luci siRNA) as a control. Cells in experiments on the left panel were maintained in 5\% CCS, whereas cells in the right panel were maintained in 1\% CCS. Cells were treated with ethanol or E2 for four hours. Nuclear- and cytoplasmic-pAKT levels were measured by Western blotting. C: Requirement of TCL1B for E2-inducible expression of Cyclin D1. Cells were transfected with siRNAs for six days and then treated with E2 for eight hours.

ensure that siRNA reduces TCL1B protein (Figure 6A, right panel). Experiments were conducted under two conditions. In the first condition, cells were maintained in $5 \%$ CCS allowing detectable PAKT in both cytoplasmic and nuclear compartments (Figure 6B, left panel). TCL1B siRNA reduced nuclear-pAKT levels without altering cytoplasmic-pAKT under this experimental condition. Similar results were obtained when siRNA against TCL1B from a different source was used (data not shown). In the second series of experiments, cells were maintained in $1 \%$ CCS, which drastically reduced only basal cytoplasmic-pAKT. Under this condition, E2 increased nuclearPAKT levels, which was reduced by TCL1B siRNA (Figure $6 \mathrm{~B}$, right panel). TCL1B siRNA reduced E2-inducible expression of Cyclin D1 in T47-D cells suggesting its importance in E2-regulated gene expression (Figure 6C, $P=0.02)$.

We examined basal and E2-induced nuclear-pAKT levels in MCF-7 and T47-D cells engineered to overexpress TCL1B. TCL1B expression in these cells is shown in Figure 7A. Basal nuclear-pAKT levels were higher in TCL1B overexpressing cells compared with cells with a control vector with no further increase on E2 treatment (Figure 7B, $P<0.005$ ). TCL1B overexpressing cells displayed an overall increase in nuclear AKT levels suggesting its role in nuclear translocation of AKT. TCL1B over- 
A

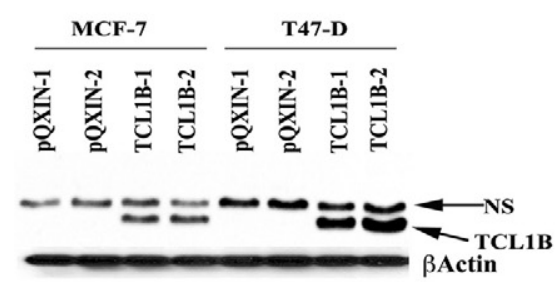

B

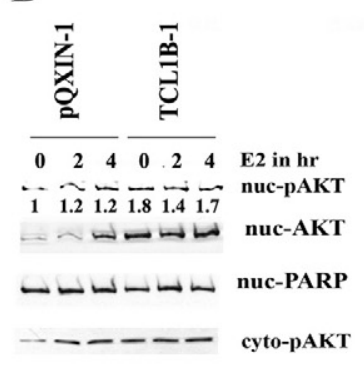

$-\infty-\infty-$ cyto-AKT

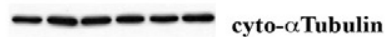

C

Figure 7. TCL1B overexpression leads to elevated basal nuclear-pAKT in MCF-7 and T47-D cells. A: TCL-1B expression in cells infected with control (pQXIN) or TCL1B coding retroviruses. NS indicates nonspecific. B: Basal and E2 regulated nuclear-pAKT levels in control and TCL1B overexpressing MCF-7 (left) and T47-D cells (right). The pAKT level in cells treated with E2 for two and four hours are also shown. C: Increased E2inducible proliferation of TCL1B overexpressing MCF-7 cells. Cell proliferation was measured by BrdU-ELISA after seven days of E2 treatment. ${ }^{*} P=$ 0.0001. D: TCL1B increases E2-inducible (clone TCL1B1) or basal (clone TCL1B2) expression of T47D cells. Cell proliferation was measured as in C. ${ }^{*} P=0.043$, untreated versus E2-treated pQXIN clone; ${ }^{* *} P=0.0001$, untreated pQXIN versus untreated TCL1B2; ${ }^{* * * *} P=0.047$, E2-treated pQXIN versus E2-treated TCL1B1. E: TCL1B overexpressing MCF-7 and T47-D cells display elevated basal Cyclin D1 compared with control pQXIN clone. Cyclin D1 expression was measured by Western blotting. F: TCL1B expression is higher in $\mathrm{ER} \alpha$-positive breast cancers $(n=229)$ compared with $\mathrm{ER} \alpha$-negative breast cancers $(n=69)$. G: Breast cancers that did not metastasize to lungs ( $n=51$ ) show higher TCL1B expression than cancers that have metastasized to lungs $(n=14)$.
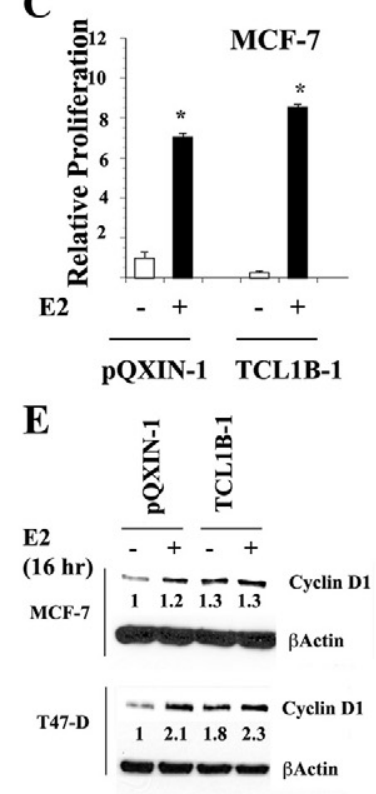
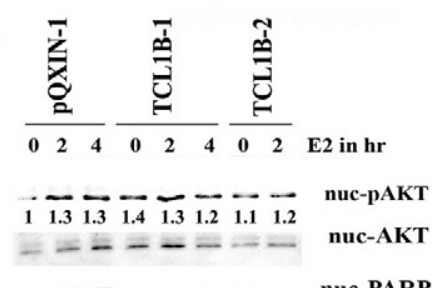

$-\infty=-\infty,-\infty$ nuc-PARP

$-\cdots-\cdots-$ cyto-pAKT

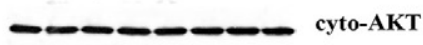

cyto- $\alpha$ Tubulin

D

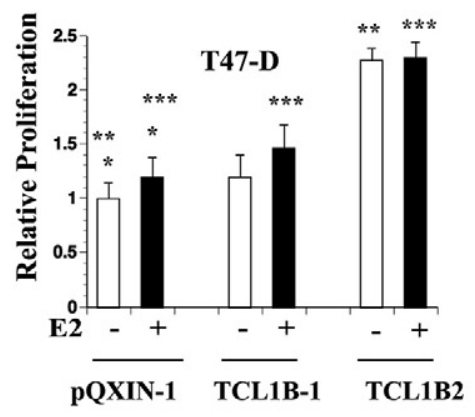

F

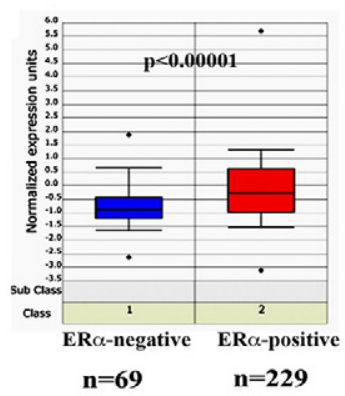

G

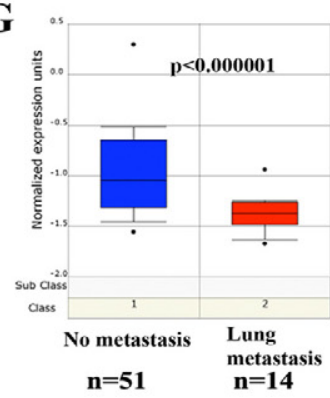

expression increased cytoplasmic pAKT in MCF-7 but not T47-D cells; the reason for this cell type-specific difference is unknown. E2-stimulated growth of TCL1B overexpressing MCF-7 cells was higher than vector control cells, consistent with the known role of AKT in increasing $\mathrm{ER} \alpha$ activity and proliferation $(P=0.0001$, Figure 7C). ${ }^{25}$ TCL1B overexpressing T47D cells displayed either increased E2-stimulated growth (clone TCL1B1) or basal growth (clone TCL1B2) compared with the vector control cells (Figure 7D). Note that the TCL1B2 clone expresses higher levels of TCL1B than the clone TCLB1 (Figure 7A).

We next examined basal and E2-inducible Cyclin D1 expression in control and TCL1B overexpressing MCF-7 and T47-D cells. Basal Cyclin D1 levels were higher in TCL1B overexpressing MCF-7 and T47-D cells compared with cells with the control vector-alone; this was more prominent in T47-D cells (Figure 7E). Thus, the results of loss (siRNA) and gain (overexpression) function studies reveal a role for TCL1B in activation of nuclear AKT in certain types of breast cancer cells and this nuclear AKT activation correlated with elevated Cyclin D1 expression.
To determine whether $\mathrm{ER} \alpha$ and TCL1B expression show a direct relationship in primary human breast cancers, publicly available gene expression data from 295 patients were analyzed. ${ }^{38}$ All patients were younger than 53 years old; 151 had lymph node-negative disease, and 144 had lymph node-positive disease. TCL1B expression was significantly higher in $\mathrm{ER} \alpha$-positive tumors than ER $\alpha$-negative tumors (Figure 7F, left panel, $P<10^{-5}$ ). A second study involving 51 cases without lung metastasis and 14 cases with lung metastasis (independent of $\mathrm{ER} \alpha$ ) showed higher TCL1B expression in breast tumors of patients without lung metastasis compared with patients with metastasis to lungs (Figure $7 \mathrm{G}$, right panel, $P<10^{-6}$ ). ${ }^{39}$

\section{Nuclear AKT Regulates Cyclin D1 Expression and Enhances Proliferation}

To determine the role of nuclear AKT in breast cancer, we examined the effect of nuclear-targeted AKT on proliferation of MCF-7 cells. Although AKT1 lacks a nuclear localization signal, it has a nuclear export signal. ${ }^{22} \mathrm{We}$ generated cells overexpressing a variant of AKT with 


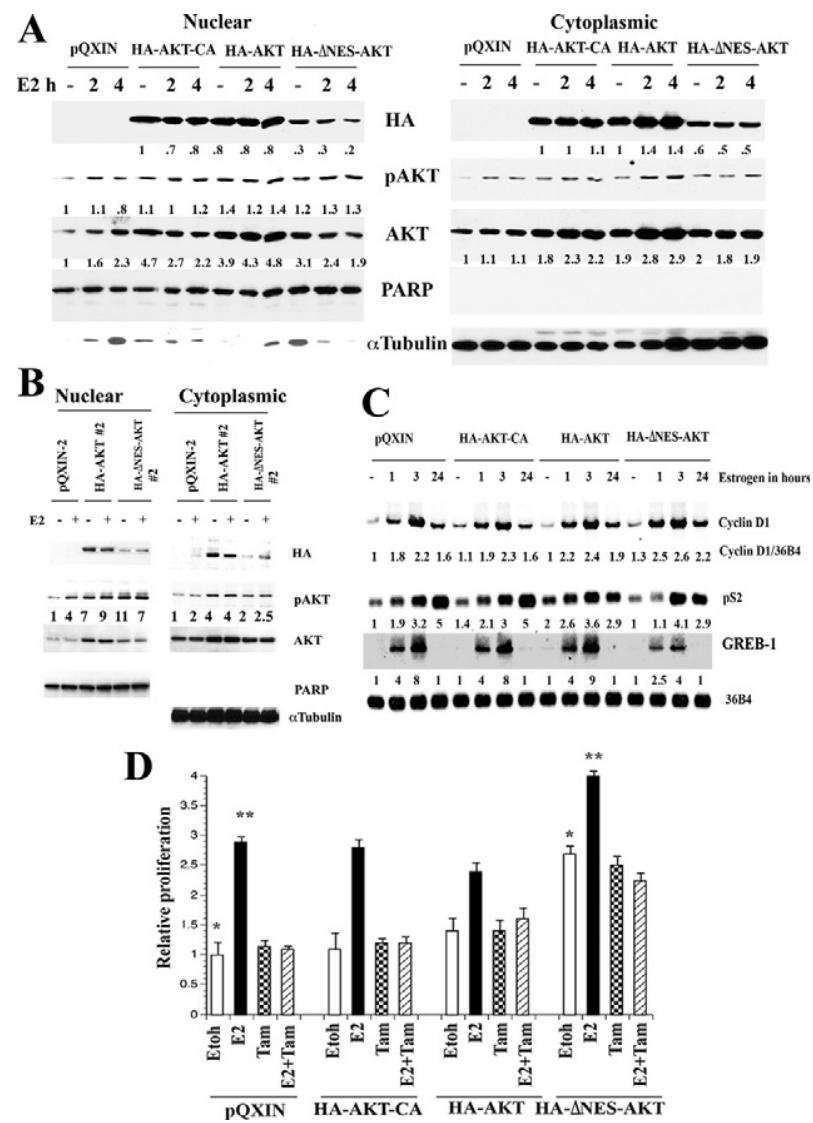

Figure 8. A: Nuclear- and cytoplasmic-AKT1 levels in stable cell lines expressing HA-AKT-CA, HA-AKT, and HA- $\Delta$ NES-AKT. Total AKT and PAKT levels in parental and transfected cells are shown. B: Nuclear- and cytoplasmic-pAKT levels in independent HA-AKT and HA- $\Delta$ NES-AKT overexpressing clones. Cells were treated with E2 for two hours. C: The effect of AKT overexpression on basal and E2-inducible Cyclin D1 expression was measured by Northern blotting. Ratio between Cyclin D1 and 36B4 (loading control) from three experiments is shown. D: HA- $\Delta$ NES-AKT overexpressing cells show elevated basal and E2-inducible proliferation. Cells were treated with ethanol (Etoh), E2 $\left(10^{-10} \mathrm{~mol} / \mathrm{L}\right)$, 4-hydroxytamoxifen $\left(10^{-6} \mathrm{~mol} / \mathrm{L}\right)$ or both and cell proliferation was measured by BrdU-ELISA after five days of treatment. 4-hydroxytamoxifen inhibited E2-inducible proliferation of HA$\Delta$ NES-AKT overexpressing cells. $\left({ }^{*} P<0.05 ;{ }^{*} P<0.01\right)$.

mutations that reduce its nuclear export to evaluate the effect of nuclear-targeted AKT1 (AKT1 1 NES) on E2-induced gene expression and cell proliferation. Cells overexpressing wild-type AKT1 (HA-AKT1) and a constitutively active AKT1 (T308D/S473D, HA-AKT1-CA) were generated as controls (Figure 8A). As expected, nuclearand cytoplasmic-pAKT levels under basal or E2-treated conditions were higher in AKT-overexpressing clones. However, there were clone-specific differences in nuclearand cytoplasmic-pAKT ratios (Figure 8, A and B). Despite lower levels of HA-AKT1 1 NES in the nucleus compared with HA-AKT, HA-AKT1 1 NES cells contained higher or equivalent levels of nuclear-pAKT compared with HA-AKT overexpressing cells (Figure 8, A and B). Additionally, HAAKT1 1 NES cells reproducibly showed elevated E2-inducible expression of Cyclin D1 (Figure 8C), the major downstream target of AKT1 in mammary tumors in animal models. ${ }^{40}$ Basal and E2-inducible expression of pS2 was unaffected by AKT overexpression. Interestingly, HAAKT1 $\triangle$ NES reduced E2-inducible expression of GREB-1, suggesting gene-specific effects of nuclear AKT in shaping the E2 response. Alternatively, nuclear AKT controls GREB-1 expression independent of E2 response. Elevated E2-inducible Cyclin D1 expression correlated with increased E2-dependent proliferation of HAAKT1 1 NES cells compared with vector control and HA-AKT1 overexpressing cells (Figure 8D). E2-induced, but not HA-AKT1 1 NES-mediated, proliferation of these cells was inhibited by tamoxifen, suggesting that E2-induced proliferation, even in the presence of nuclear AKT, shows some sensitivity to the anti-estrogenic effects of tamoxifen $(P=0.0001)$.

\section{Discussion}

AKT activation is an early event in breast cancer, often seen at the in situ stage, ${ }^{20}$ raising the possibility of $\mathrm{AKT}$ functioning as an initiating oncogene. A number of animal models support such a possibility. For example, AKT1 is essential for MMTV-V-H-Ras-induced mammary tumors. ${ }^{41}$ MMTV-AKT1 transgenic mice develop ER $\alpha$-positive breast cancers on exposure to carcinogen, highlighting a link between ER $\alpha$ and AKT1 in breast cancer. ${ }^{42}$ Furthermore, AKT1 deficiency is sufficient to suppress mammary tumors in PTEN+/- mice. ${ }^{43}$ Although the role of AKT1 in tumor initiation is unequivocal, its role in metastasis remains controversial. Some studies have shown inhibition of invasion and/or metastasis by AKT1, whereas others have shown a facilitatory role. ${ }^{40,41,44-46}$ One of the reasons for this controversy may be that the subcellular localization (as demonstrated in this study) as well as the cancer subtype determines the oncogenic activities of AKT. To our knowledge, this is the first study that has addressed the above issue by evaluating activated AKT levels within the context of subcellular localization and breast cancer subtypes.

Functions of AKT1 that may limit tumor progression are beginning to be explored. AKT1 limits breast cancer cell motility and invasion through NF-AT transcription factor. ${ }^{44}$ The ratio between AKT1 and AKT2 determines the invasive capacity of breast cancer cells; AKT2 but not AKT1 suppresses the expression of microRNAs miR200a, $\mathrm{b}$, and $\mathrm{c}$ and enhances self-renewal of cancer stem cells, with this function of AKT2 antagonized by AKT1. ${ }^{47} \mathrm{MiR}$ 200 microRNAs function as invasion and metastasis suppressors by preventing the epithelial to mesenchymal transition. Thus, although AKT1 may increase proliferation of breast cancer cells, as reported previously in transgenic models ${ }^{48}$ and evident from our in vitro studies in MCF-7 cells (Figure 8), cancers with activated AKT1 may not be aggressive because of low frequency metastasis. Additionally, cancers with hyperactivated AKT are sensitive to reactive oxygen species-mediated apoptosis while being resistant to conventional chemotherapy. ${ }^{49}$ Boehme and colleagues described a novel function for AKT in DNA-dependent protein kinase-mediated stabilization of p53 during ionizing radiation. ${ }^{50}$ During ionizing radiation, DNA-dependent protein kinase activated only nuclear AKT, and only nuclear PAKT was capable of stabilizing p53, thus revealing nucleus-specific AKT ac- 
tivation pathway and function for nuclear-pAKT. Activation of AKT in this context could be viewed as a good prognostic indicator. However, additional studies are essential to determine the AKT isoform that is phosphorylated in cancer and the influence of the specific isoform in controlling the expression of proliferationassociated genes linked to poor prognosis. In this respect, HA-AKT1 1 NES increased proliferation and Cyclin D1 expression in MCF-7 cells. Based on Oncomine ${ }^{\mathrm{TM}}$ (Compendia Bioscience, Inc., Ann Arbor, MI) analysis and a recent study, elevated expression of Cyclin D1 is often observed in ER $\alpha$-positive breast cancers with better prognosis. ${ }^{51}$

Analyses of two independent datasets in this study confirm an association of nuclear-pAKT with $\mathrm{ER} \alpha+$ / $\mathrm{PR}+$ or luminal A subtype, a breast cancer subgroup connoting a favorable prognosis. Furthermore, we demonstrate a mechanistic link between ER $\alpha$ and nuclear-pAKT, which may be partly mediated through TCL1B. We emphasize that there may be other mechanisms responsible for nuclear accumulation of PAKT in $E R \alpha$-positive breast cancer cells, which still need to be explored. Nuclear-pAKT functions in these tumors may include activation of $\mathrm{ER} \alpha$ through phosphorylation, DNA binding, and coactivator association. ${ }^{25,52}$ Thus, in patients with luminal A type tumors, the presence of nuclear-pAKT may be a manifestation of their addiction to an ER $\alpha$ :E2:nuclear-pAKT signaling network for proliferation; this dependence could also make these tumors susceptible to anti-estrogens. In keeping with this hypothesis, expression of ER $\alpha$ phosphorylated at the AKT phosphorylation site S167 is associated with a good prognosis in breast cancer: PAKT levels in this patient cohort positively correlated with S167 phosphorylation. ${ }^{53}$ Additionally, an AKT1_E17K mutation, which correlates with an increase in AKT phosphorylation, is observed exclusively in $\mathrm{ER} \alpha+/ \mathrm{PR}+$ tumors and is associated with favorable prognosis. ${ }^{54}$ Furthermore, during the revision of this manuscript, Kalinsky and colleagues showed that a PIK3CA H1047R mutation, which in cell-based assays cause robust AKT activation, is associated with ER $\alpha$-positivity, node-negativity, HER2-negativity, and improved long-term survival. ${ }^{55,56}$ Thus, all of the studies noted above emphasize the unique clinical relevance of PAKT in ER $\alpha$-positive breast cancers.

It is important to consider our results in the context of other studies that have suggested a role for activated AKT in anti-estrogen resistance. ${ }^{57-59}$ Most of the in vitro studies relied on constitutively active myristylated forms of AKT1 or AKT2; these constitutively active forms appear to have lost isoform specific functions, at least with respect to repressing miR-200 microRNA ${ }^{47}$ and thus may not actually recapitulate the function of phosphorylated AKT isoforms. Another possible explanation is that in the absence of signals that activate nuclear AKT in ER $\alpha+$ tumors or acquisition of resistance to anti-estrogens through growth factor signaling could result in cytoplasmic localization and/or activation of AKT. Consistent with this possibility, Cui and colleagues demonstrated a role for pAKT in tamoxifen resistance in patients whose tu- mors lack PR expression. ${ }^{58}$ We hope that our results and those from other recent publications will trigger a new interest in evaluating AKT activation and/or function in distinct cell compartments; this might lead to reassessment of its tumor subtype type-dependent oncogenic potential. Understanding the pathobiology of resistance to hormonal therapy in ER $\alpha+$ tumors might entail consideration of the functions of PAKT in different cellular compartments as well as mechanisms that control its activity in these distinct compartments.

\section{Acknowledgments}

We thank Dr. Mathew D. Ringel (Ohio State University) for AKT expression vectors, Nikhil Luktuke for assistance in ChIP-chip data analysis, Shankar Ganesh for database analysis, and Sheila Bhat for technical assistance.

\section{References}

1. Martelli AM, Faenza I, Billi AM, Manzoli L, Evangelisti C, Fala F, Cocco L: Intranuclear 3'-phosphoinositide metabolism and Akt signaling: new mechanisms for tumorigenesis and protection against apoptosis? Cell Signal 2006, 18:1101-1107

2. Dillon RL, White DE, Muller WJ: The phosphatidyl inositol 3-kinase signaling network: implications for human breast cancer. Oncogene 2007, 26:1338-1345

3. Datta SR, Brunet A, Greenberg ME: Cellular survival: a play in three Akts. Genes Dev 1999, 13:2905-2927

4. Sarbassov DD, Guertin DA, Ali SM, Sabatini DM: Phosphorylation and regulation of Akt/PKB by the rictor-mTOR complex. Science 2005 , 307:1098-1101

5. Carpten JD, Faber AL, Horn C, Donoho GP, Briggs SL, Robbins CM Hostetter G, Boguslawski S, Moses TY, Savage S, Uhlik M, Lin A, Du J, Qian YW, Zeckner DJ, Tucker-Kellogg G, Touchman J, Patel K, Mousses S, Bittner M, Schevitz R, Lai MH, Blanchard KL, Thomas JE: A transforming mutation in the pleckstrin homology domain of AKT1 in cancer. Nature 2007, 448:439-444

6. Manning BD, Cantley LC: AKT/PKB signaling: navigating downstream. Cell 2007, 129:1261-1274

7. Samuels Y, Wang Z, Bardelli A, Silliman N, Ptak J, Szabo S, Yan H, Gazdar A, Powell SM, Riggins GJ, Willson JK, Markowitz S, Kinzler $\mathrm{KW}$, Vogelstein B, Velculescu VE: High frequency of mutations of the PIK3CA gene in human cancers. Science 2004, 304:554

8. Plas DR, Thompson CB: Akt-dependent transformation: there is more to growth than just surviving. Oncogene 2005, 24:7435-7442

9. Ahn JY, Liu X, Liu Z, Pereira L, Cheng D, Peng J, Wade PA, Hamburger AW, Ye K: Nuclear Akt associates with PKC-phosphorylated Ebp1, preventing DNA fragmentation by inhibition of caspase-activated DNase. EMBO J 2006, 25:2083-2095

10. Camper-Kirby D, Welch S, Walker A, Shiraishi I, Setchell KD, Schaefer E, Kajstura J, Anversa P, Sussman MA: Myocardial Akt activation and gender: increased nuclear activity in females versus males. Circ Res 2001, 88:1020-1027

11. Shiraishi I, Melendez J, Ahn Y, Skavdahl M, Murphy E, Welch S, Schaefer E, Walsh K, Rosenzweig A, Torella D, Nurzynska D, Kajstura J, Leri A, Anversa P, Sussman MA: Nuclear targeting of Akt enhances kinase activity and survival of cardiomyocytes. Circ Res 2004, 94:884-891

12. Hayward CS, Kelly RP, Collins P: The roles of gender, the menopause and hormone replacement on cardiovascular function. Cardiovasc Res 2000, 46:28-49

13. Sorlie T, Perou CM, Tibshirani R, Aas T, Geisler S, Johnsen H, Hastie $T$, Eisen MB, van de Rijn M, Jeffrey SS, Thorsen T, Quist H, Matese JC, Brown PO, Botstein D, Eystein Lonning P, Borresen-Dale AL: Gene expression patterns of breast carcinomas distinguish tumor subclasses with clinical implications. Proc Natl Acad Sci U S A 2001, 98:10869-10874 
14. Badve S, Nakshatri H: Oestrogen-receptor-positive breast cancer: towards bridging histopathological and molecular classifications. J Clin Pathol 2009, 62:6-12

15. Badve S, Turbin D, Thorat MA, Morimiya A, Nielsen TO, Perou CM, Dunn S, Huntsman DG, Nakshatri H: FOXA1 expression in breast cancer correlation with luminal subtype a and survival. Clin Cancer Res 2007, 13:4415-4421

16. Eeckhoute J, Keeton EK, Lupien M, Krum SA, Carroll JS, Brown M: Positive cross-regulatory loop ties GATA-3 to estrogen receptor alpha expression in breast cancer. Cancer Res 2007, 67:6477-6483

17. Cheang MC, Chia SK, Voduc D, Gao D, Leung S, Snider J, Watson M, Davies S, Bernard PS, Parker JS, Perou CM, Ellis MJ, Nielsen TO: Ki67 index. HER2 status, and prognosis of patients with luminal B breast cancer, J Natl Cancer Inst 2009, 101:736-750

18. Sutherland BW, Kucab J, Wu J, Lee C, Cheang MC, Yorida E, Turbin D, Dedhar S, Nelson C, Pollak M, Leighton Grimes H, Miller K, Badve S, Huntsman D, Blake-Gilks C, Chen M, Pallen CJ, Dunn SE: Akt phosphorylates the $Y$-box binding protein 1 at Ser102 located in the cold shock domain and affects the anchorage-independent growth of breast cancer cells. Oncogene 2005, 24:4281-4292

19. Wolf I, Bose S, Williamson EA, Miller CW, Karlan BY, Koeffler HP: FOXA1: growth inhibitor and a favorable prognostic factor in human breast cancer. Int J Cancer 2007, 120:1013-1022

20. Bose S, Chandran S, Mirocha JM, Bose N: The Akt pathway in human breast cancer: a tissue-array-based analysis. Mod Pathol 2006, 19:238-245

21. Sturn A, Quackenbush J, Trajanoski Z: Genesis: cluster analysis of microarray data. Bioinformatics 2002, 18:207-208

22. Saji M, Vasko V, Kada F, Allbritton EH, Burman KD, Ringel MD: Akt1 contains a functional leucine-rich nuclear export sequence. Biochem Biophys Res Commun 2005, 332:167-173

23. Bhat-Nakshatri P, Wang G, Appaiah H, Luktuke N, Carroll JS, Geistlinger TR, Brown M, Badve S, Liu Y, Nakshatri H: AKT Alters genome-wide estrogen receptor alpha binding and impacts estrogen signaling in breast cancer. Mol Cell Biol 2008, 28:7487-7503

24. Carroll JS, Meyer CA, Song J, Li W, Geistlinger TR, Eeckhoute J, Brodsky AS, Keeton EK, Fertuck KC, Hall GF, Wang Q, Bekiranov S, Sementchenko V, Fox EA, Silver PA, Gingeras TR, Liu XS, Brown M: Genome-wide analysis of estrogen receptor binding sites. Nat Genet 2006, 38:1289-1297

25. Campbell RA, Bhat-Nakshatri P, Patel NM, Constantinidou D, Ali S, Nakshatri H: Phosphatidylinositol 3-kinase/AKT-mediated activation of estrogen receptor alpha: a new model for anti-estrogen resistance. J Biol Chem 2001, 276:9817-9824

26. Asada M, Yamada T, Ichijo H, Delia D, Miyazono K, Fukumuro K, Mizutani S: Apoptosis inhibitory activity of cytoplasmic p21(Cip1/ WAF1) in monocytic differentiation. EMBO J 1999, 18:1223-1234

27. Perou CM, Sorlie T, Eisen MB, van de Rijn M, Jeffrey SS, Rees CA Pollack JR, Ross DT, Johnsen H, Akslen LA, Fluge O, Pergamenschikov A, Williams C, Zhu SX, Lonning PE, Borresen-Dale AL, Brown PO, Botstein D: Molecular portraits of human breast tumours. Nature 2000, 406:747-752

28. Carroll JS, Liu XS, Brodsky AS, Li W, Meyer CA, Szary AJ, Eeckhoute J, Shao W, Hestermann EV, Geistlinger TR, Fox EA, Silver PA, Brown M: Chromosome-wide mapping of estrogen receptor binding reveals long-range regulation requiring the forkhead protein FoxA1. Cell 2005, 122:33-43

29. Altomare DA, Testa JR: Perturbations of the AKT signaling pathway in human cancer. Oncogene 2005, 24:7455-7464

30. Van de Sande T, Roskams T, Lerut E, Joniau S, Van Poppel H, Verhoeven G, Swinnen JV: High-level expression of fatty acid synthase in human prostate cancer tissues is linked to activation and nuclear localization of Akt/PKB. J Pathol 2005, 206:214-219

31. Carey LA, Perou CM, Livasy CA, Dressler LG, Cowan D, Conway K, Karaca G, Troester MA, Tse CK, Edmiston S, Deming SL, Geradts J, Cheang MC, Nielsen TO, Moorman PG, Earp HS, Millikan RC: Race, breast cancer subtypes, and survival in the Carolina Breast Cancer Study. JAMA 2006, 295:2492-2502

32. Trotman LC, Alimonti A, Scaglioni PP, Koutcher JA, Cordon-Cardo C, Pandolfi PP: Identification of a tumour suppressor network opposing nuclear Akt function. Nature 2006, 441:523-527

33. Kato T, Muraski J, Chen Y, Tsujita Y, Wall J, Glembotski CC, Schaefer E, Beckerle M, Sussman MA: Atrial natriuretic peptide promotes cardiomyocyte survival by cGMP-dependent nuclear accumulation of zyxin and Akt. J Clin Invest 2005, 115:2716-2730

34. Teitell MA: The TCL1 family of oncoproteins: co-activators of transformation. Nat Rev Cancer 2005, 5:640-648

35. Pekarsky Y, Koval A, Hallas C, Bichi R, Tresini M, Malstrom S, Russo G, Tsichlis P, Croce CM: Tcl1 enhances Akt kinase activity and mediates its nuclear translocation, Proc Natl Acad Sci U S A 2000 97:3028-3033

36. Fiorenza MT, Torcia S, Canterini S, Bevilacqua A, Narducci MG, Ragone G, Croce CM, Russo G, Mangia F: TCL1 promotes blastomere proliferation through nuclear transfer, but not direct phosphorylation, of AKT/PKB in early mouse embryos. Cell Death Differ 2008, 15:420-422

37. Berry M, Metzger D, Chambon P: Role of the two activating domains of the oestrogen receptor in the cell-type and promoter-context dependent agonistic activity of the anti- oestrogen 4-hydroxytamoxifen. EMBO J 1990, 9:2811-2818

38. van de Vijver MJ, He YD, van't Veer LJ, Dai H, Hart AA, Voskuil DW, Schreiber GJ, Peterse JL, Roberts C, Marton MJ, Parrish M, Atsma D, Witteveen A, Glas A, Delahaye L, van der Velde T, Bartelink $H$, Rodenhuis S, Rutgers ET, Friend SH, Bernards R: A gene-expression signature as a predictor of survival in breast cancer. N Engl J Med 2002, 347:1999-2009

39. Minn AJ, Gupta GP, Siegel PM, Bos PD, Shu W, Giri DD, Viale A, Olshen AB, Gerald WL, Massague J: Genes that mediate breast cancer metastasis to lung. Nature 2005, 436:518-524

40. Ju X, Katiyar S, Wang C, Liu M, Jiao X, Li S, Zhou J, Turner J, Lisanti MP, Russell RG, Mueller SC, Ojeifo J, Chen WS, Hay N, Pestell RG: Akt1 governs breast cancer progression in vivo, Proc Natl Acad Sci U S A 2007, 104:7438-7443

41. Skeen JE, Bhaskar PT, Chen CC, Chen WS, Peng XD, Nogueira V, Hahn-Windgassen A, Kiyokawa H, Hay N: Akt deficiency impairs normal cell proliferation and suppresses oncogenesis in a p53-independent and mTORC1-dependent manner. Cancer Cell 2006, 10:269-280

42. Blanco-Aparicio C, Perez-Gallego L, Pequeno B, Leal JF, Renner O, Carnero A: Mice expressing myrAKT1 in the mammary gland develop carcinogen-induced ER-positive mammary tumors that mimic human breast cancer. Carcinogenesis 2007, 28:584-594

43. Chen ML, Xu PZ, Peng XD, Chen WS, Guzman G, Yang X, Di Cristofano A, Pandolfi PP, Hay N: The deficiency of Akt1 is sufficient to suppress tumor development in Pten+/- mice. Genes Dev 2006, 20:1569-1574

44. Yoeli-Lerner M, Yiu GK, Rabinovitz I, Erhardt P, Jauliac S, Toker A: Akt blocks breast cancer cell motility and invasion through the transcription factor NFAT. Mol Cell 2005, 20:539-550

45. Irie HY, Pearline RV, Grueneberg D, Hsia M, Ravichandran P, Kothari $\mathrm{N}$, Natesan S, Brugge JS: Distinct roles of Akt1 and Akt2 in regulating cell migration and epithelial-mesenchymal transition. J Cell Biol 2005, 171:1023-1034

46. Liu H, Radisky DC, Nelson CM, Zhang H, Fata JE, Roth RA, Bissell $\mathrm{MJ}$ : Mechanism of Akt1 inhibition of breast cancer cell invasion reveals a protumorigenic role for TSC2, Proc Natl Acad Sci U S A 2006, 103:4134-4139

47. Iliopoulos D, Polytarchou C, Hatziapostolou M, Kottakis F, Maroulakou IG, Struhl K, Tsichlis PN: MicroRNAs differentially regulated by Akt isoforms control EMT and stem cell renewal in cancer cells, Sci Signal 2009, 2:ra62

48. Maroulakou IG, Oemler W, Naber SP, Tsichlis PN: Akt1 ablation inhibits, whereas Akt2 ablation accelerates, the development of mammary adenocarcinomas in mouse mammary tumor virus (MMTV)ErbB2/neu and MMTV-polyoma middle T transgenic mice. Cancer Res 2007, 67:167-177

49. Nogueira V, Park Y, Chen CC, Xu PZ, Chen ML, Tonic I, Unterman T, Hay N: Akt determines replicative senescence and oxidative or oncogenic premature senescence and sensitizes cells to oxidative apoptosis. Cancer Cell 2008, 14:458-470

50. Boehme KA, Kulikov R, Blattner C: p53 stabilization in response to DNA damage requires Akt/PKB and DNA-PK. Proc Natl Acad Sci U S A 2008, 105:7785-7790

51. Agarwal R, Gonzalez-Angulo AM, Myhre S, Carey M, Lee JS, Overgaard J, Alsner J, Stemke-Hale K, Lluch A, Neve RM, Kuo WL, Sorlie T, Sahin A, Valero V, Keyomarsi K, Gray JW, Borresen-Dale AL, Mills GB, Hennessy BT: Integrative analysis of cyclin protein levels identifies cyclin b1 as a classifier and predictor of outcomes in breast cancer. Clin Cancer Res 2009, 15:3654-3662 
52. Likhite VS, Stossi F, Kim K, Katzenellenbogen BS, Katzenellenbogen JA: Kinase-specific phosphorylation of the estrogen receptor changes receptor interactions with ligand, deoxyribonucleic acid, and coregulators associated with alterations in estrogen and tamoxifen activity. Mol Endocrinol 2006, 20:3120-3132

53. Jiang J, Sarwar N, Peston D, Kulinskaya E, Shousha S, Coombes RC, Ali S: Phosphorylation of estrogen receptor-\{alpha\} at Ser167 is indicative of longer disease-free and overall survival in breast cancer patients. Clin Cancer Res 2007, 13:5769-5776

54. Stemke-Hale K, Gonzalez-Angulo AM, Lluch A, Neve RM, Kuo WL, Davies M, Carey M, Hu Z, Guan Y, Sahin A, Symmans WF, Pusztai L, Nolden LK, Horlings H, Berns K, Hung MC, van de Vijver MJ, Valero V, Gray JW, Bernards R, Mills GB, Hennessy BT: An integrative genomic and proteomic analysis of PIK3CA. PTEN, and AKT mutations in breast cancer. Cancer Res 2008, 68:6084-6091
55. Gymnopoulos M, Elsliger MA, Vogt PK: Rare cancer-specific mutations in PIK3CA show gain of function. Proc Natl Acad Sci U S A 2007, 104:5569-5574

56. Kalinsky K, Jacks LM, Heguy A, Patil S, Drobnjak M, Bhanot UK, Hedvat CV, Traina TA, Solit D, Gerald W, Moynahan ME: PIK3CA mutation associates with improved outcome in breast cancer. Clin Cancer Res 2009, 15:5049-5059

57. Kirkegaard T, Witton CJ, McGlynn LM, Tovey SM, Dunne B, Lyon A Bartlett JM: AKT activation predicts outcome in breast cancer patients treated with tamoxifen. J Pathol 2005, 207:139-146

58. Cui X, Schiff R, Arpino G, Osborne CK, Lee AV: Biology of progesterone receptor loss in breast cancer and its implications for endocrine therapy. J Clin Oncol 2005, 23:7721-7735

59. Perez-Tenorio G, Stal O: Activation of AKT/PKB in breast cancer predicts a worse outcome among endocrine treated patients. $\mathrm{Br} J$ Cancer 2002, 86:540-545 